\title{
Comparative Study on the Foraging Habits of Two Species of Soricine Shrews
}

\author{
Hiroko YOSHINO \& Hisashi ABE
}

\begin{abstract}
Yoshino H. \& Abe H., 1984: Comparative study on the foraging habits of two species of soricine shrews. Acta theriol., 29, 3: 35-43 [With 4 Figs.].

We compared the daily activities and digging abilities of Sorex unguiculatus Dobson, 1890 and $S$. caecutiens saevus Thomas, 1907 in the laboratory. Activities of the two species increased at night, but $S$. caecutiens was more nocturnal than $S$. unguiculatus. The level of feeding activity was almost constant throughout the day, and its proportion to the total activity was higher in smaller $S$. caecutiens than in larger $S$. unguiculatus. A very clear difference in digging abilities was shown, i.e., $S$. unguiculatus frequently used a deep underground habitat and food, whereas $S$. caecutiens mainly utilized resources on the ground surface and in shallow soil.

[Institute of Applied Zoology, Faculty of Agriculture, Hokkaido University, Sapporo, 060, Japan]
\end{abstract}

\section{INTRODUCTION}

Five species of shrews occur in Hokkaido, Japan. Two of them, Sorex unguiculatus and $S$. caecutiens, are common, ubiquitous species and often coexist in the same habitat, though they are rarely found in abundance at the same time. S. unguiculatus has a large body with a relatively short tail, small hind feet, short ears, and very large hands with long claws, and it feeds heavily on earthworms. S. caecutiens, on the other hand, has a smaller body with a relatively long tail, large hind feet, large ear;, and small hands with short claws, and it feeds much on spiders. From these characteristics, Abe (1968) designated the former to be a semidigger and the latter not to be a digger. Stratificational separation in foraging habits of the two shrews, however, has not been measured actually. The main purpose of this paper is to discuss this subject from results obtained in a feeding experiment and observations of the foraging habits of the above species in the laboratory.

\section{METHODS}

\subsection{Type of Cage and Shrews Used}

The experimental cage was composed of two parts, a flat cage and vertical narrow cages. The flat cage was made of sheets of zinc and plate glass (the front wall), and it measured $57 \times 73 \times 40(\mathrm{~h}) \mathrm{cm}$. This cage was used as the main living area and for observations of the daily cycle of activity. The cage contained 
$10 \mathrm{~cm}$ depth of garden soil and a little humus. The soil was gently compressed, with sprinkling water and covered with leaf litter.

The shrews were placed individually in the cage and provided with cotton for nesting material and water in a small tray. Pupae of the house fly (Musca domestica L.) were used as food material. The pupae were produced and kept cold in the laboratory before the experiment. About 120 percent weight of pupae to the body weigth of each shew were divided into 60 parts, and each was placed at the following 60 points in the cage: 15 points per each layer of soil, the surface (under leaf litter, $0 \mathrm{~cm}$ ) and $2 \mathrm{~cm}, 5 \mathrm{~cm}$, and $10 \mathrm{~cm}$ depths. The number of pupae per point was about $7-8$ for $S$. unguiculatus and $4-5$ for S. caecutiens.

The vertical narrow cage was made of two pieces of wide plate glass $(70 \times 50 \mathrm{~cm})$. two narrow sheets of zinc $(8 \times 50 \mathrm{~cm})$ and a lid of zinc. This cage was provided with $30 \mathrm{~cm}$ depth of soil and leaf litter on the surface. The two vertical narrow cages and the flat cage were connected by wire mesh tubes, but the exit of the flat cage was closed when the cage was used for observations of the daily cycle of activity. When used for the experiments of foraging habits, the shutter to the connecting tube was removed, and the house fly pupae were placed only in the vertical cages in the same manner as that mentioned above. In this case, all the bait points were placed close to the inside of the glass walls to enable observation of feeding. All of the points fixed at the designated depths were separated from those at other depths by moving them horizontally slightly to prevent the bait from being set along the same perpendicular line.

The following shrews were used for the present study. Thirteen S. unguiculatus (6 males, 5 females and 2 sex unknown), and $5 S$. caecutiens ( 3 males and 2 females), all of which had been trapped in a wind shelterbelt in the suburbs of Sapporo, Hokkaido. With the exception of 2 adult males of $S$. unguiculatus, all animals were juveniles or subadults.

The cages were placed in the laboratory, but light, temperature, and other conditions were not regulated. The experiments were conducted in the summer and autumn of 1981.

\subsection{Daily Cycle of Activity}

Each shrew was kept in the flat cage for 3 to 5 days before the experiments to allow it to become habituated to its surroundings, and then the daily cycle of activity was observed. Activities were classified into the following 4 categories: exploring, digging (or burrowing), feeding and resting. We recorded the activities for 30 seconds at every 5 minutes for 24 hours per indinvidual and also the places were observed, i.e., ground surface or underground.

In this experiment we used $12 \mathrm{~S}$. unguiculatus and $4 \mathrm{~S}$. caecutiens, and represented the degree of activity by percentage frequency of each category per 1 hour.

\subsection{Foraging Habits}

After the observations of the daily cycle of activity were made the shutter separating the vertical cages was removed, and the shrews was left for 1 to 2 days. Then house fly pupae were placed in the vertical cages as mentioned previously and left for 24 hours. The shrews usually consumed all of the pupae at one point and then moved on to other points; the foraging rate was determined by calculating the number of points consumed. In this experiment we used 13 
$S$, unguiculatus and $5 S$, caecutiens and repeated the foraging experiments for each individual 4 times (days). Seven hundred and eighty point data for each layer of soil, i.e., in total 3120 point data for $S$, unguiculatus and 300 and 1200 in total for $S$. caecutiens were obtained.

In addition to the above, another experiment was conducted to analyze the foraging process in different depths of soil, i.e., foraged points were measured at every 6 hours for 3 samples of $S$. unguiculatus and 6 of $S$. caecutiens. In this experiment bait setting and the start of the experiments were shifted 4 hours every day to prevent any effect of daily cycle of activity.

\section{RESULTS}

\subsection{Daily Cycle of Activity and Underground Activity}

Average daily cyclez of activities of the two species of shrews are given in Fig. 1 and 2. In $S$. unguiculatus, there was great individual variation in the daily activity level, but the basic pattern of activity, i.e., a particular rhythm of activity and rest, was similar among

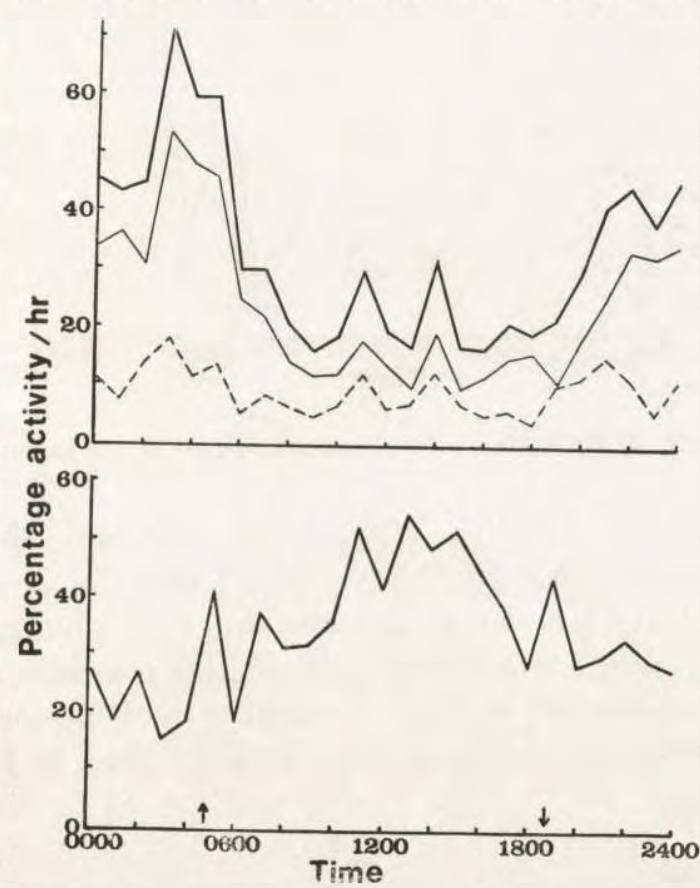

Fig. 1. Daily cycle of activity (upper) and underground stay (lower) in Sorex unguiculatus.

Heavy line: total activity: light line: exploring and digging; broken line: feeding. Arrows indicate average times of sunset and sunrise.

individuals. The data are not shown in the figure because of the) averaged data. The daily activity of $S$. caecutiens was less variable per individual. 
The two species of shrews rapidly became active at around sunset, and their activity reached a peak at around 2 to 3 o'clock at night. However, the activity level rapidly decreased to a low level in the daytime after sunrise. The proportion of daytime to night activity was 0.74 in $S$. unguiculatus and 0.5 in $S$. caecutiens, i.e., the latter was more nocturnal in activity.

In $S$. unguiculatus, the activity cycle at night was variable individually, and a term of activity lasted for 30 to 50 minutes, or 90 minutes at the longest. The period of resting varied from 5 to 25 minutes. The activity cycle was more apparent in the daytime, showing a term of about 120 minutes in which resting time accounted for more than 80 percent of the time. In $S$. caecutiens, the activity cycle was less apparent because of great variation in the term of resting. However, the term of the cycle tended to be shorter than in S. unguiculatus.

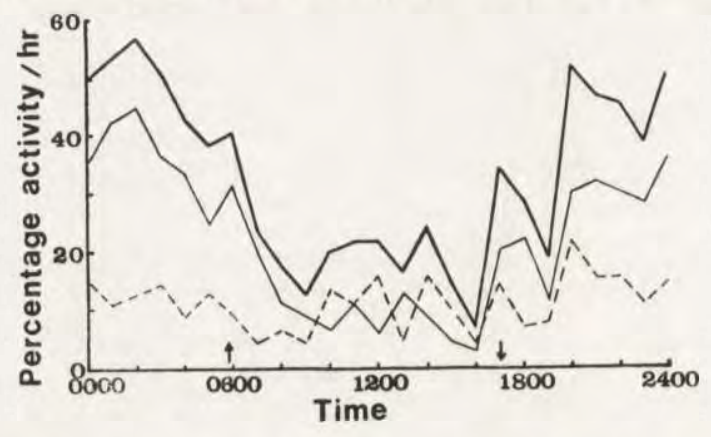

Fig. 2. Daily cycle of activity in Sorex caecutiens. Cf. for legend in Fig. 1.

The level of feeding activity was almost constant throughout the day in the two species, though the variation trend was rather similar to that of other activities, and was less variable individually as compared with the other activities. From these facts, the increase of activity at night is mostly attributable to that of digging and exploring activities. The average frequency of daily feeding activity was 26.1 in $S$. unguiculatus and 30.8 in S. caecutiens. The proportion of feeding activity to the entire daily activity was 23.2 percent and 33.9 percent, respectively.

Fig. 1 shows the average daily cycle of underground activity including burrowing and resting in burrows or the nest cavity in the soil of S. unguiculatus. The latter composed most of the activity in the daytime. The shrews spent 33.3 percent of the day underground, and contrary to the daily cycle of whole activity, the underground activity was more frequent in the daytime. The underground activity of $S$. caecutiens was very scarce, being recorded only twice in two individuals which had remained in a shallow burrow during the first experiment in the flat 
cage. This species usually took rest in the nest made on the ground surface.

From these observations, we concluded tentatively, considering the limited laboratory conditions, that $S$. unguiculatus takes rest underground in the daytime except for a low level of feeding activity, and becomes very active on the ground surface at night, whereas $S$. caecutiens has similar habits except for its significant lesser degree of underground activity.

\subsection{Digging Habits}

In $S$. unguiculatus 99.6 percent points containing baits on the ground surface were consumed, 93.8 percent at $2 \mathrm{~cm}$ depth, and the feeding rate decreased to 46.4 percent at $10 \mathrm{~cm}$ depth (Fig. 3). The feeding rate was more variable individually at deeper points, but most of the individuals dug down to depths of 20 to $30 \mathrm{~cm}$.

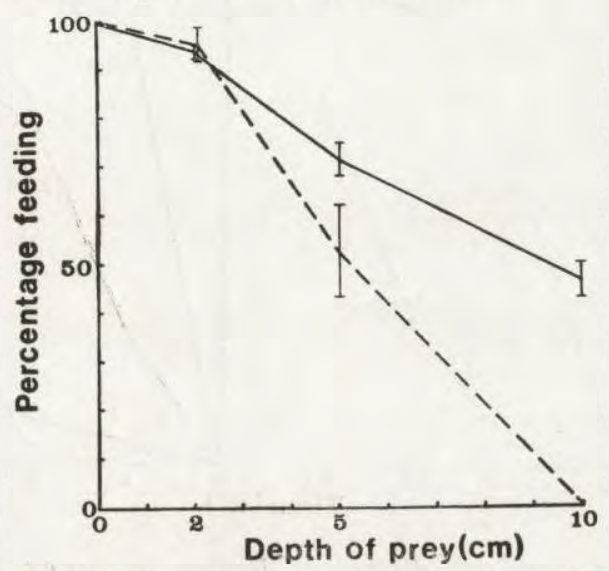

Fig. 3. Average feeding rates of pupae buried at different depths.

Solid line: Sorex unguiculatus; broken line: $S$. caecutiens; vertical lines: standard errors of the means.

Two types of digging activities were roughly discriminated, i.e., surface digging and burrowing. The former was also observed in S. caecutiens. The latter consisted of digging longer, deeper tunnels and was observed more frequently at night. However, the shrews usually rebuilt the tunnels in 1 to 2 days and never maintained them as a fixed system as do true moles Mogera spp.

Younger shrews weighing 7.2 to $7.5 \mathrm{~g}$ tended to be more active on the ground surface and older individuals weighing 8.5 to $10.5 \mathrm{~g}$ appeared to prefer staying underground. This observation, however, requires further observations for confirmation.

In $S$. caecutiens, all points of baits on the ground surface and 95.2 
percent at $2 \mathrm{~cm}$ depth were eaten, but only one half of the points (52.4 percent) at $5 \mathrm{~cm}$ depth were used. No bait at $10 \mathrm{~cm}$ depth was eaten (Fig. 3). The shrews often dug shallowly at the ground surface but never dug into the depths as did $S$. unguiculatus.

From these observations, it is apparent that digging ability was clearly different between the two species.

\subsection{Foraging Process}

Foraging process in relation to the vertical distribution of bait was measured with advancing time (Fig. 4). S. unguiculatus had used more or less all of the depths by about 6 hours after the start of the experiment, and they used the deepest layer $(10 \mathrm{~cm})$ more frequently than the $5 \mathrm{~cm}$ layer in spite of the fact that about 70 percent of the bait remained at

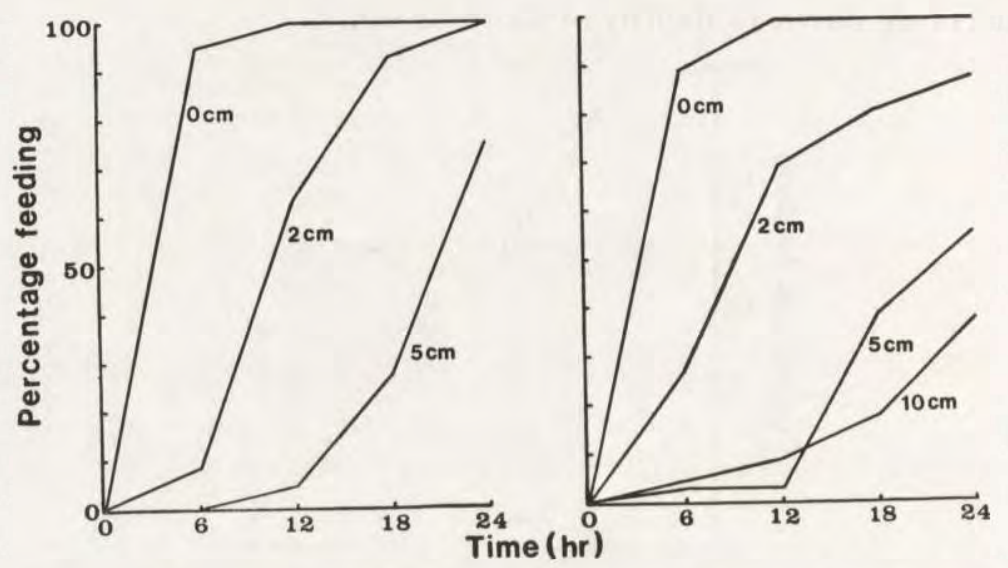

Fig. 4. Foraging processes at different depths in Sorex caecutiens (left) and $S$. unguiculatus (right).

$2 \mathrm{~cm}$ depth at this time. Baits at $0 \mathrm{~cm}$ and $2 \mathrm{~cm}$ depths were rapidly consumed by the shrews by 12 hours, and then the shrews intensively attacked points at deeper layers. The shrews of $S$. caecutiens progressively consumed bait one by one from $0 \mathrm{~cm}$ to $5 \mathrm{~cm}$ depths. The final feeding rates at 24 hours in this experiment were rather different from those of the former experiment, but the general tendencies were similar between the two experiments.

\subsection{Searching and Feeding Behaviors}

In this experiment, we also observed the searching and feeding behaviors of the two species. S. unguiculatus exactly and rapidly dug 
down to the points of $2 \mathrm{~cm}$ depth. When they found pupae, they sometimes ate them at the point, but they usually carried one of them under the leaf or to the nest to eat and later returned to the point until all the pupae were consumed. They also randomly dug down from the ground surface to find deeper points, but 12.2 percent of the feeding activity amounted to horizontal digging underground.

In order to find inactive food such as pupae placed on the ground surface or hidden in the shallow soil, scent appeared to be important in prey location. However, it was not so effective in deep soil, so that the finding of pupae by the shrews appeared to depend on chance.

The feeding behavior of $S$. caecutiens was similar to that of the previous species. However, when they dug to the points at $2 \mathrm{~cm}$ depth, they could not reach the depth at once because of their poor digging ability. They never showed horizontal digging underground, but dug from the ground surface even when they reached the points at $5 \mathrm{~cm}$ depth.

\section{DISCUSSION}

The present results indicate a relatively clear difference in the digging ability and foraging habits of the two species of shrews, and support the previous observation of Abe (1968). Okhotina (1974) showed a similar result in her work on food habits, digging ability, daily activity and food resources of 8 species of shrews, including the present species, in the Maritime Province of Siberia. These ecological components are important for coexisting shrews, and stratificational segregation in habitat use is one of the important measures to reduce interspecific competition (Hawes 1977).

Churchfield (1980) showed that $S$. araneus also has burrowing habits similar to those of $S$. unguiculatus. We conjectured that these species are ecological equivalents with different geographic distributions (Abe 1983).

Of the 5 species of shrews occurring in Hokkaido, Crocidura dsinezumi and $S$. minutissimus are very rare species with localized small populations, and therefore are less important ecologically in the small mammal community. S. gracillimus has a general ecology and morphology which are rather similar to those of $S$. caecutiens, and the two species are overlapped with each other in geographic distribution in the northern and eastern districts and mountain areas of Hokkaido. One of the interesting problems concerning these two species is to observe the mechanism of their segregation.

The activity of the present two shrews increased at night, which may be attributable at least partly to the nocturnal activity of prey such as soil and leaf-litter dwelling invertebrates. The frequent daytime 
activity of $S$. unguiculatus may be related to the high level of underground activity in which shrews are concealed in soil.

Many works have appeared on the daily cycle of activity of shrews, but in only a few is feeding activity measured separately (Crowcroft, 1957; Shillito, 1963; Pernetta, 1977; Buchalczyk, 1972; Godfrey, 1978). Buchalczyk (1972) showed the daily cycle of feeding activity to be similar to that of locomotion (exploring and digging in the present work) in $S$. araneus, a finding which differs from our result. Her "feeding activity" was shown by the number of visits by shrews to the bait box and by behavior which seemed to include some locomotions; therefore, her data may not be comparable with ours. Godfrey (1978) measured the feeding and other activities of Crocidura suaveolens by radar. This shrew showed a nocturnal habit in total activity, although the feeding activity was almost constant throughout the day, which was similar to that of the present species. Godfrey (1978) calculated the number of visits of shrews to the foodpot as feeding activity, a method which seems to be more accurate than that of Buchalczyk (1972). If our results by direct observation are reliable, we can conclude that the feeding activity of shrews is rather constant throughout the day and does not increase heavily at night along with other activities.

\section{REFERENCES}

1. Abe H., 1968: Classification and biology of Japanese Insectivora (Mammalia). II. Biological aspects. J. Fac. Agr. Hokkaido Univ., 55: 429-458.

2. Abe H., 1983: Distribution and radiation in soricid shrews. Honyurui Kagaku 46: $49-57$ (in Japanese).

3. Buchalczyk A., 1972: Seasonal variations in the activity of shrews. Acta theriol., 17: 221-243.

4. Churchfield J. S., 1980: Subterranean foraging and burrowing activity of the common shrew. Acta theriol., 25: 451-459.

5. Crowcroft P., 1957: The life of the shrew. Max Reinhardt: 1-166. London.

6. Godfrey G. K., 1978: The activity pattern in white-toothed shrews studied with radar. Acta theriol., 23: $381-390$.

7. Hawes M. L., 1977: Home range, territoriality, and ecological separation in sympatric shrews, Sorex vagrans and S. obscurus. J. Mamm., 58: 354-367.

8. Okhotina M. V., 1974: Morfo-ékologičeskie osobennosti različnych vidov burozubok (Sorex, Insectivora), obuslovlivajušcie vozmožnost' ich sovmiejstnogo suščestvovanija. Fauna i Ekologija nazemn. Pozvonočnych Juga Dal'nego Vostoka SSSR, 17: 42-57.

9. Pernetta J. C., 1977: Anatomical and behavioural specializations of shrews in relation to their diet. Can. J. Zool., 55: 1442-1453.

10. Shillito J. F., 1963: Field observations on the growth, reproduction, and activity of a woodland population of the common shrew Sorex araneus $\mathrm{L}$. Proc. Zool. Soc., Lond., 140: 99-114.

Accepted, November 16, 1983. 
Hiroko YOSHINO i Hisashi ABE

\section{POROWNAWCZE BADANIA ZWYCZAJOW POKARMOWYCH}

\section{DWOCH GATUNKOW RYJOWEK}

\section{Streszczenie}

Autorzy porównywali w warunkach laboratoryjnych, aktywność dobową i zdolności do kopania u Sorex unguiculatus Dobson, 1890 i $S$. caecutiens saevus Thomas, 1907. Aktywność u obu gatunków wzrasta nocą, lecz $S$. caecutiens była bardziej „nocna” niż S. unguiculatus (Ryc. 1, 2). Poziom aktywności pokarmowej był prawie stały w ciągu doby a jego udział w ogólnej aktywności był wyższy u mniejszej $S$. caecutiens niż większej $S$. unguiculatus. Wykazano wyraźne różnice w zdolnościach do kopania, tzn. S. unguiculatus częściej używała podziemnych korytarzy i pokarmu tam znajdowanego, podczas gdy $S$. caecutiens korzystała głównie z pokarmu znajdującego się na powierzchni ziemi, lub plytko pod powierzchnią (Ryc. 3, 4). 